\title{
Culture and Political Understanding on Muslimat Nahdlatul Ulama (NU) in East Java
}

\author{
Ishomuddin $^{1 *}$, Laili Abidah ${ }^{2}$, Rinikso Kartono ${ }^{3}$, Wahyudi ${ }^{4}$ \\ ${ }^{1}$ Professor of Sociology of Islamic Society of University of Muhammadiyah Malang, \\ ${ }^{2}$ Doctor Candidate of Social and Political Sciences of University of Muhammadiyah Malang \\ ${ }^{3}$ Doctor of Social Welfare of University of Muhammadiyah Malang \\ ${ }^{4}$ Doctor of Sociology of University of Muhammadiyah Malang \\ *Corresponding Author: Ishomuddin, Professor of Sociology of Islamic Society of University of \\ Muhammadiyah Malang

\begin{abstract}
In the context of its activities, since the NU Muslimat was established, it was almost all the archipelago had the same activities called religious activities, which included (1) manaqiban (2) dibaan, (3) reboan, (3) Muslimat Hajj Association, (4) recitations with themes around the pillars of Islam. But there is a phenomenon of shifting understanding of the elite and NU Muslimat members to the themes of recitation and the movement of political da'wah, especially at the place where the research was conducted.The activities at NU Muslimat which have been carried out not only as a routine activity of the Muslim community, but for the wider role of the NU Muslimat in general and its members to occupy strategic positions in the government or legislative members. From the above phenomena, the objectives of this study are as follows: to understand the culture and political understanding of NU Muslimat citizens in East Java.This research was conducted using a qualitative approach. Data collection uses observation, interviews, and document. Data analysis was carried out using the Interactive Analysis Model of Miles, Hubermen, Saldhana.
\end{abstract}

Keywords: Culture, Political Culture, Politics, Understanding, Muslimat NU

\section{INTRODUCTION}

In the context of its activities, since the NU Muslimat was born, in almost all the archipelago had the same activities called religious activities but lately there has been a phenomenon of shifting the understanding of the elite and Muslimat members towards the themes of recitation and the movement of da'wah, especially at the place where this research was conducted and the shift began to appear in the last ten years (Zuhri, 1979).

After the birth of the PKB in 1998, since then the condition of the NU Muslimat began to be concentrated in politics and gradually this organization was drawn to practical political interests (Ridwan, 2008). Starting from the elite in the structure to the NU Muslimat members, they felt that the most important part of PKB supporters. Preliminary interviews conducted with several administrators and members, showed and concluded in the meantime, they generally said that understanding the activities at NU Muslimat which had been carried out not only as a routine activity of Islamic mental religious formation for the general public or Muslimat members but for the sake of the broader role of NU Muslimat for this nation must be aimed at political interests which benefit NU Muslimat in general and its members to occupy strategic positions in the government or council members. From this understanding, this has an impact on the changes in the themes and contents of the recitation held even though the forms of activity have not changed. Based on the aforementioned phenomenon, the purpose of this research is to understand the culture and political understanding of NU Muslimat citizens in East Java.

\section{The Dinamics of Political Culture in Nu}

\subsection{Political Culture in NU}

There are several previous studies related to the research themes, namely the research conducted by Haris (2015) has relevance to this topic, "Political Participation of NU and Muslimat Cadres in 
History", NU's political movement as a NU religious and Muslimat organization as an autonomous body visible in the trajectory of the history of the nation. The problem that arises is the extent to which NU participates in national politics and how much NU Muslimat represent themselves in politics. Through a typology approach, this study explores NU and NU Muslimat political contributions in the trajectory of the nation's history. Various data show that NU and NU Muslimat participate passively and actively in national politics. In the colonial period NU entered the passive participant typology, but in the following period took the form of non-conventional active participants. This active participant was evident when NU issued a Jihad Resolution to defend independence. This participation was then channeled through Masyumi, then established political parties independently. NU Muslimat passive participation began to be recognized in 1938, and was only recognized as an active participant in 1946. Muslimat became an active participant fighting for gender equality in 1954. Five years later Muslimat became a participant gladiator, and began to show his gender role simultaneously by raising the issue strategic information that aims to strengthen rights, resources and aspirations for women to participate in the public sphere including practical politics.

Political participation is an effort to check and balances in a country. The participation of NU as the first largest organization in Indonesia cannot be underestimated. In historical records, the footsteps of the NU organization have never been absent (Fadeli \& Subhan, 2007). Participation carried out since the colonial era was seen in influencing colonial government policies, up to the current reform era. As explained above, NU is not silent under any circumstances. Serious efforts are made to defend people's rights in religion. The sacrifices made by figures are not small, so that the lives will be willing to be sacrificed. The imposition of colonialist ideologies was obstructed by NU figures. This can be seen from coercion to respect the Siekeirei tradition which is considered contrary to Islamic teachings. As an excess, K.H. Hasyim Asy'ari, as the chairman of the NU Executive Board (PB) finally issued a resolution asking the government of the Republic of Indonesia to act decisively against the Dutch, while at the same time fighting for sabilillah. Islamic boarding schools were transformed into the headquarters of Hizbullah and Sabilillah which were driven by the Kyai to fight colonialism in Indonesia (Aboebakar, 1957). Likewise with NU Muslimat, since the beginning independence took an active role in participating in calling for the voices of truth in the public sphere. The political role of women is increasingly needed considering that their population is not inferior to men. A large capital in the electoral process, on the other hand the level of education of women in Indonesia increased significantly which in the end fostered a new awareness of the importance of women's involvement in politics. This awareness raising then gave birth to movements among women about their equal rights with men. Given that so far, political marginalization of women has taken place simultaneously, so the demands for improving the conditions of their rights and gender justice are very much discussed. The political role of women in formal political structures according to the author is as follows:

First, female politicians must establish partnerships with women's problem assessment institutions and women's activity activists. The results of research and assessment of these institutions can be useful in decision making. This is important, because so far many policies are not in accordance with the needs of the target group as a result of their own input errors. Second, creating political independence in the process of political decision making. Women's political independence has always been a rare item. Desire women to be political by using steadfast principles without the shadow of men and even their political parties. Emancipation in politics in a short time can be realized. Third, in carrying out its formal political role, female politicians must maintain equality with men. Formal political opportunities for women are a form of reasonable political participation. Because the political survival of this nation also requires the touch of women both as subjects and objects. Again, the opportunity for formal political participation of women needs to be supported and appreciated fairly. For women, this opportunity should not be interpreted as an arena of revenge, because so far it has been the object of male political masculinity.

Zaenuri (2015), "The Role of the Nahdlatul Ulama as a Political Party in 1952-1973 in Pasuruan, East Java". Nahdlatul Ulama (NU) was one of the Islamic organizations that emerged during the Indonesian national movement, but in $1952 \mathrm{NU}$ turned into a political party after breaking away from Masyumi. The decision to issue NU from Masyumi and become a Political Party was stated in the 19th Congress in Palembang with 61 votes agreed, 9 votes refused, and 7 abstained. While the branch of the NU Party in Pasuruan Regency was established in 1952, after the results of the 19th Congress in 
Palembang were decided. The purpose of this study was to describe the role of NU as a political party in 1952-1973 in Pasuruan which included (1) the standing background and development of the Nahdlatul Ulama as Political Parties in 1952-1973 in Indonesia; (2) the background of the establishment of Nahdlatul Ulama in Pasuruan Regency in 1935; (3) the role of Nahdlatul Ulama as a political party in 1952-1973 in Pasuruan Regency.This research uses historical methods. This method consists of five stages, namely topic selection, heuristics (collection of written sources, maps, and oral sources/interviews), source criticism (external and internal), interpretation and historiography. The method is used to compile facts, describe and draw conclusions about what happened in the past.

Based on the results of the study, it was concluded that NU left Masyumi and established a Political Party due to the role of Kiai Wahab Hasbullah. Pasuruan regency is one of the biggest bases of NU, this is inseparable from the role of Kiai Nawawi who became member of PBNU in 1926 and is an influential kiai in Pasuruan. However, only in 1935 did the NU branch of Pasuruan regency be officially established by appointing Kiai Muhammad Dahlan as chairman. The role of the NU party in the 1955 and 1971 general elections was inseparable from the role of Islamic boarding schools, kiai, santri, and the political elite. In the 1955 and 1971 elections the NU Party in Pasuruan regency always got the most votes. During the campaign to win the NU Party in Pasuruan in the 1955 elections, the clerics did not hesitate to go directly to the field to become campaigners, besides the NU campaign strategy in Pasuruan was also obtained from a "hidden" campaign, namely during the recitation. In the 1971 election the NU campaign strategy was not much different from the 1955 elections, the difference being in the 1971 campaign there were few restrictions from the government because at that time there was intervention. Based on the results of the study, he suggested to other researchers to continue or dig deeper into the history of NU in Pasuruan regency, because in this study there are still many shortcomings that must be corrected.

\subsection{Political Culture}

Understanding of political culture is a pattern of behavior of a society and its orientation towards life in politics, be it the administration of state administration, politics of government, law, customs, and norms of habit that are lived out by every individual in society everyday There is also a mention that political culture is the perception of society in a country that is manifested in a pattern of attitudes towards political events that occur. So, the notion of political culture is values that develop and are practiced by certain communities in politics.

Politics has touched all of the social order so that it influences the attitudes and behavior of the community. According to Amind and Powel, there are several things that are included in the scope of politics, namely: (1) The way people perceive politics is obtained from broad or narrow knowledge. (2) The orientation of society towards politics that is influenced by attachment, involvement, and rejection. (3) Orientation that assesses objects in political events.

In order to better understand the meaning of political culture, we can refer to the opinions of the following experts and figures. According to Alan R. Ball (1963)), the notion of political culture is an arrangement consisting of attitudes, beliefs, emotions, and values of society that are related to political systems and political issues. According to Austin Ranney (1996), Political culture is a set of views about politics and government that are held together; a pattern of orientation-oriented political objects. According to Albert Widjaja, (1982) Political culture is the political aspect of a system of values which consists of ideas, knowledge, customs, superstitions and myths that are known and recognized as the majority of society. This culture gives rational to reject or accept other values and norms. Gabriel Almond and Sidney Verba (1966), political culture is the attitude of citizens' orientation towards the political system and its various parts and attitudes towards the role of citizens in the system. According to Mochtar Mas'oed and Colin Mac Andrews (2000), understanding political culture is the attitude and orientation of society in a country towards the life of the state and political government. And According to Miriam Budiardjo, (2012) Political culture is the whole of political views, such as norms, patterns of orientation towards politics and views of life in general.

Political culture in a country can be recognized by paying attention to its characteristics. In general, the characteristics of political culture are as follows: (1) There are elements of regulating power in government, both at the center and in the regions. (2) There is a policy-making process by the government. (3) Patterns of behavior of officials and government officials of a country. (4) There are several political parties and all their activities in the community. (5) Not infrequently there is turmoil 
in the community in addressing the power of the government. (6) There is political culture related to the issue of legitimacy.

Indonesian people have experienced many things in the political field. According to Rusadi Kantaprawira (1999), there are three types of political culture in Indonesia, namely: First, Parochial Political Culture. Understanding political culture Parochial is a culture where the level of political participation of the people is still very low. This type of political culture is often found in traditional societies that are simple. According to Mochtar Mas'oed and Colin Mc. Andrews (2000), Parochial politics occurs because people do not know or are unaware of the existence of government and the political system. Parochial political characteristics are as follows: The scope is small and narrow. (1) The community is apathetic. (2) Public knowledge about politics is still very low. (3) Communities tend to be ignorant and withdraw from political territory. (4) The community is very rarely faced with the political system. (5) Low public awareness about the existence of a center of authority and power in a country.

Second, the Political Culture of the Subject /Kaula / Subject political culture is a culture where people tend to be more advanced in the economic and social fields. Although the people are still relatively passive, they have understood the existence of a political system and are obedient to the law and government officials. The political characteristics of Kaula / Subject are: (1) The existence of full awareness of the community towards government authorities. (2) The community is still passive towards politics. (3) Some residents provide input and requests to the government, but have accepted the rules from the government. (4) The community accepts decisions that cannot be corrected or challenged. (5) The community has been aware of and paid attention to the general and special political system of the output object, while awareness of the input and as a political actor was still quite low.

Third, Participant's Political Culture. Political Culture Participants are a culture where the community has a high awareness of a political system, the structure of political processes, and administration. The political characteristics of the Participants are: (1) There is public awareness about the rights and responsibilities of political life. (2) The community does not directly accept the situation, but gives a conscious assessment of political objects. (3) Political life in the midst of society acts as a means of transaction. (4) The community has high awareness as an active and role citizen in politics.

Indonesian people generally carry out this culture in the life of the state, and in everyday life. In Indonesia itself, political culture has experienced a mix between Parochial, Kaula, and Participants. The mixing of various cultures is caused by various factors, including: (1) Diversity that exists in Indonesian society. (2) There are influences from outside cultures, relics of colonialism, feudalism, paternalism, and others. (3) The existence of the nature of primordial bonds where there are regional, tribal, and religious sentiments. (4) There is an interaction between modernization and habits or traditions in society. (5) Indonesian culture which still embodies paternalism, and patrimonial nature (father's inheritance). The following are some examples of political culture in Indonesian society: (a) Participating in the Election for those who have fulfilled the requirements. (b) Following demonstrations in a peaceful and orderly manner. (c) Participate in community forums to express opinions and aspirations.

\section{Methodology}

\subsection{Research Paradigm}

In accordance with the objectives and unit of analysis, this study uses the social definition paradigm. Exemplar of this paradigm is Weber's work on social action. Weber's work helps direct attention to social definitions in the way that social actors define their social situations and the effects of social definitions in maintaining actions and interactions (Ritzer, 1988, 1992, 2005, 2012, 2014). In studies that use this paradigm, they prefer to use in-depth interviews, observations. Observation is a typical method of the social definition paradigm. The social definition paradigm according to Soeprapto (2002: 88-89) emphasizes the nature or substance of social reality, which is more subjective and individual.

\subsection{Research Approach}

This research uses a qualitative approach. This qualitative approach prioritizes the techniques of indepth interviews and observation. Observation is a typical method of the social definition paradigm. 
The data obtained are primary and secondary data. Primary data was obtained using interview guideline instruments prepared for informants that were relevant to the data needs Patton (1980), namely, the first Muslim community members who were active in the NU Muslim organization and were also party administrators. Secondly, the NU Muslimat who became the legislature both at the district and provincial levels from the Pasuruan District. While secondary data is data in the form of documents or information written or printed. Related to document data, there are differences in terms of documents and records. Guba and Lincoln (1981: 228), Denzim \& Lincoln (1994), Creswell (2009) define as follows: Record is any written statement prepared by a person or institution for the purpose of testing an event or presenting accounting. Documentation is any written material or film, other than a record, which is not prepared because of the request of an investigator. This study leads to the use of documents rather than records, but does not rule out the possibility that records are also used as long as the researcher finds them. Documents and records are used according to Guba and Lincoln for reasons that can be justified as follows:

- Because it is a stable, rich and encouraging source.

- Useful as evidence for a test.

- Both are useful and in accordance with qualitative research, because they are of a natural nature, in accordance with the context, born and in context.

- Records are relatively inexpensive and not difficult to obtain, but documents must be found and found.

- Both are not reactive so it is difficult to find them with the content study technique.

- The results of the content review will open up opportunities to further expand the body of knowledge of what is being investigated.

The documents used by researchers in this case include personal documents and official documents obtained from the NU Muslimat office in the District. In addition, researchers also searched for secondary data by conducting study decisions and data accessed through the internet. Using this documentation technique aims to complete the data needed.

\subsection{Research Subject}

The subjects of this study were NU Muslimat residents in Pasuruan District, East Java. The Pasuruan regency community has a relatively homogeneous background, both in terms of background in life history, culture, and economic conditions. Apart from being inhabited by Javanese people, Pasuruan City also has Arab and Indian people, but there are not many. The informants and subjects of this study were NU Muslimat members who were active in organizing as well as being active in the party and having knowledge that was considered more extensive than the other members. The selection of informants and research subjects was carried out by theoretical sampling with certain criteria. In qualitative research, the emphasis on data sourced from in-depth interviews is very important. Therefore qualitative research emphasizes the depth of data obtained from the number of informants needed.

\subsection{Data Analysis}

The first part of the analysis is carried out by applying an analytical method commonly used in field research. In this case the researcher agrees with the steps written by Babbie (1975: 221-224) as follows: (a) data analysis in field research is conducted intertwined with the process of observation, (b) Trying to find similarities and differences with social symptoms observed, namely finding the behavior of parents/guardians of students or normative standards that apply universally in the broader scope of social systems, (c) Forming taxonomy of behavior with respect to observed social phenomena, (d) Arranging tentatively theoretical propositions, with regard to relationships between categories developed or produced conclusions, (e) Conduct further observations of behavior related to temporary theoretical propositions to produce conclusions, (f) Evaluate temporary theoretical propositions to produce conclusions, (g) To prevent subjective drawing of conclusions, efforts are made to develop inter-subject through discussion with others and maintaining social sensitivity and awareness as a researcher. Data collected was analyzed using interactive models Miles, Hubenrman, and Saldhana (2014). This model looks at analysis as three concurrent activities: (1) condensation of 
data, (2) display data, and (3) conclusion drawing/verification. In this way, explore each of these components more deeply when the researcher reads the data.

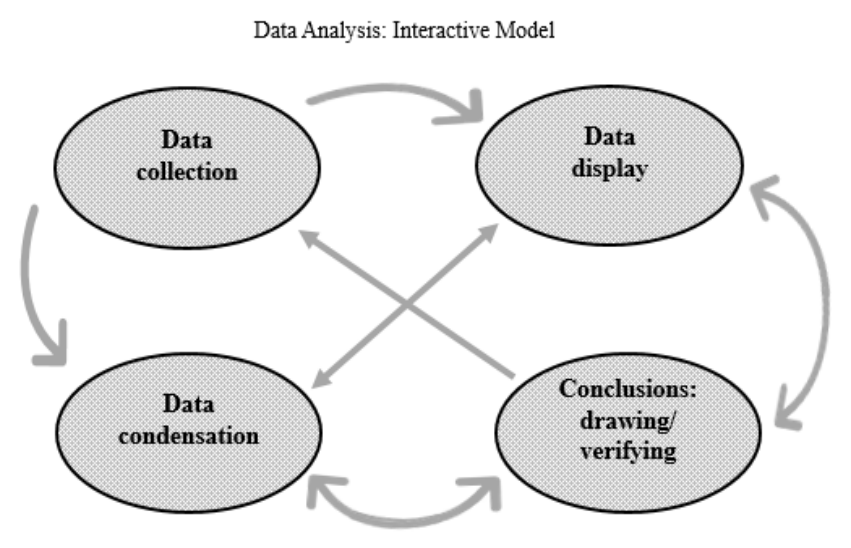

Miles, M.B., \& Huberman, A.M. (1994). Qualitative data analisys: An expanded sourcebook (2nd ed.)

\subsubsection{Data Condensation}

Data condensation is not something separate from analysis. That is part of the analysis. Researcher's decision - which data is encoded and which must be revoked, which category summarizes a number of pieces, which are all analytic choices. Condensation data form analysis that sharpens, sorts, focuses, discards, and arranges data in a way that "final" can be made and verified conclusions. By condensing data, researchers do not mean qualifications, qualitative data can be changed in many ways: through summaries or paraphrases. In this way a larger pattern can be included, and so on. Sometimes, it might be useful to disguise data to be large (for example, analysts decide that programs are seen as having a "high" or "low" effectiveness), but this is not always necessary.

\subsubsection{Data Display}

The second main flow of analysis activity is data display. In general, data displays are organized and compressed information that allows drawing and action conclusions. In everyday life, the display varies from gasoline to newspapers to Facebook status updates. Help us view displays understand what is happening and do something - either analyzing it further or taking action - based on that understanding.

As with data condensation, the display and use are not separate from analysis - this is part of the analysis. Designing the view - deciding the rows and columns for qualitative data and deciding which data, which must be included in the cell - is analytic activity. (designing the display also has clear data condensation implications).

\subsubsection{Drawing and Verifying Conclusions}

The third activity is drawing conclusions and verification. From the beginning of data collection, qualitative analysts interpret what is meant by recording patterns, explanations, flow of cause and effect, and propositions. Competent researchers make this conclusion lightly, maintain openness and skepticism, but conclusions are still there, not clear at first, then increasingly explicit and confusing. "Final" conclusions may not appear until data collection is complete, depending on the size of the body of the record fields, coding, storage, and retrieval methods used; sophistication of researchers; and deadlines that must be met.

Conclusions are also verified when analysts continue. Verification may be as short as the second thought that comes to the analyst's mind during writing with a short visit back to the field notes; or perhaps through and outlining, with lengthy arguments and reviews among workers to develop inter subjective consensus or with extensive efforts to replicate findings in other data sets.

In this view, qualitative data analysis is a company that is continuous and repetitive. Data condensation issues, display, and conclusions/verification play a role as episode analysis follows each other. Such a process is actually no more complex, conceptually, than the analytical mode used by quantitative researchers. Like their qualitative counterparts, they must be preoccupied with data 
condensation (how to calculate, standard deviation), with displays (correlation tables, regression prints), and by verification conclusions (level of significance, differences in experimental/control groups). But such activities are carried out through clear and well-known methods; guided by canon; and is usually more sequential than repetitive or cycle. Qualitative researchers are in a more fluid and more human position.

\section{RESUlTS AND DisCUSSIONS}

From the data that has been obtained from observations, in-depth interviews in the form of dialogue and discussion with the subject of research and documentation collected, the results are in the form of electronic data in the form of speeches about political culture and their understandings of Islamic politics and politics. From a number of subjects selected in this study, the data that was in accordance with the research questions were then processed, condensed and analyzed to obtain conclusions. The following are the results of the analysis and conclusions obtained.

NU followers and elite leaders prefer to say that NU is a cultural movement. Because NU is seen as an Islamic movement that can unite itself with local culture. Islam will not be able to live without unifying itself with local culture. The NU movement follows in the footsteps of the "Wali Songo" who penetrate local cultures that are incorporated into Islamic culture. This kind of Islamic movement is called "reflection" which is to unite or accommodate culture into Islamic teachings so that any culture and anywhere can be united with Islamic teachings (Ishomuddin, 2006). Reflections on local culture not only concern social, economic, educational problems, but also issues related to politics.

In this context, NU followers are always subject to local conditions that are used by propaganda and political tools by clerics or clerics at the local and regional levels. NU followers are subject to the commands and influences of their leaders by holding the principle of "sam'an wa tha'atan" in all matters of life. Political problems are a very important matter of life for NU and NU Muslimat citizens, because they are considered to determine the fate of the nation's life, especially the NU and NU Muslimat citizens. The culture that exists within the NU community is a culture created by its elites or ulama as a tool to maintain and control their respective communities. Although it is generally seen that the NU community seems to be the same in matters of mutual interest, in reality each ulama builds their respective nominations, namely maintaining their followers or followers. The large number of Islamic boarding schools and their respective leaders have different cultures showing different visions. This is what causes the NU and NU Muslimat communities to have different cultural backgrounds. For example: there is an NU Islamic boarding school that teaches Islamic education that is very fanatical about a madzab, there are Islamic boarding schools that teach Islam to be more open and not too fanatical about certain schools. And there are also very moderate Islamic boarding schools.

The conditions of Islamic education institutions or Islamic boarding schools in the NU environment above, give birth to graduates or generations who have different insights and thoughts especially on political issues. This has given rise to the character of political culture in the NU community until now. Political culture based on educational experiences and life experiences of every NU member creates differences in views and thoughts. Why are there different views about politics? Because political culture is built on the basis of "stock of konowledge" science and life experience that it has. Although fellow NU followers, their views and thoughts about Islamic politics and politics show differences. This is evidenced in the data of in-depth interviews and observations of activities carried out by researchers.

The political culture in the NU community always has dynamics and changes depending on the interests of the elite even though it does not come out of the cultural roots of the NU community. For his followers, this is a consequence of their obedience to the elite leaders in all matters of life. The principle of "sami'na wa atho 'na" which is embedded in each person of NU followers towards leaders or scholars gave birth to the characteristics of his political culture.

The understanding of NU Muslimat residents regarding politics based on the data collected through in-depth interviews is as follows:In general, information is obtained that the difference in understanding of the essence, the relationship between Islam and politics has become a long-standing discourse, even this has been a very important topic in the body of Muslims since the time of the Prophet and the Caliphate today (Sjadzali, 1990). Islamic leaders or Islamic political experts are still 
different in understanding the essence of Islam and politics. Why does this happen? Caused by the stock of knowledge about Islam and politics that is owned by the scholars and Umara, in addition to the swift social and cultural changes that occur in society caused by developing knowledge and technology.

This difference continues, especially in Muslims who dominate the Indonesian nation due to the desired group interests and leadership, Islam is confronted with non-Muslims. Such conditions also influence the thinking, views of people in the Muslim body in Indonesia in seeing the essence of Islam and politics, as well as practical politics.

\subsection{National Awakening Party (PKB) as NU Muslimat Political Aspirations}

NU is a social and religious (Islamic) organization that continues to keep up with the times. NU, as an Islamic organization that has the largest number of followers in Indonesia, feels responsible for human development in Indonesia. If other Islamic or non-Islamic organizations take on roles in other fields, NU tries to play a role in all aspects, especially human development. Although it was realized by NU that the task was very heavy considering that there were still many NU people in Indonesia living and living in villages that were not yet affordable from the NU elites who were in the cities. In its dynamics, even though $\mathrm{NU}$ is a socio-religious organization, $\mathrm{NU}$ is not blind to political problems, moreover in its history NU has been a party, and is still active in the National Awakening Party (PKB). Thus, every NU Muslimat may support the party supported by NU. According to the NU Muslimat, politics is very important for every Muslim because the Prophet Muhammad also carried out strategies in broadcasting Islam in his time. The Prophet also set up a strategy for warfare against infidels qurays. In the current context the strategy is political. It is just that the prophet did not directly establish the party in a narrow sense, namely the political party or practical politics. But all the movements carried out by the Prophet were actually good politics and sometimes had to move Muslims to fight against infidels. If we as followers of Muhammad, especially for the nahdhiyin and more specifically the Muslimat, it must support the efforts made by the ulama and kyai in fighting for Islam, including supporting political parties established by the kyai or at least the parties supported by the scholars and clerics.

From the statement above, the member of NU Muslimat explicitly said that Islam and its movements were never separated from the party because in its history Islam was very close to political movements, both strategic politics (high politics), as well as practical politics, party politics (low politics). Prophet's da'wah was secretly a strategy to invite people to explain the essence of Islam and then they were attracted to Islam and after that they converted to Islam. The practical politics carried out by the Prophet were to set a strategy for war against unbelievers. The Battle of Badr, the Khandak War, the Battle of Uhud, was inflated with Islamic slogans and flags. So the core of the understanding of the narrators of the management informants as well as political actors mentioned above is that political and political practice cannot be separated from Islam itself.

\subsection{Islamic Citizens Must Have Practical Politics}

Muslims in facing life's problems must be politically or strategically defending Islam. This was exemplified by the prophet. So, politics is a strategy of life, the life of Muslims to maintain attacks from outside. To do that then in the present context is through political parties. Because without a party, in Indonesia, it is very difficult to seize power. With that power will get the opportunity to take policies and regulate other people to benefit Muslims.

The above understanding has actually existed in the present nahdhiyin people. Politics is no longer taboo, especially if you read the history of NU's dynamics since the organization was founded until now. As the wing of NU, Muslims in general have realized that the current model of NU's struggle is right. Because of that, it must support the political policies outlined by the NU elite, the ulama, the kyai in determining the struggle of Muslims in Indonesia.

From this expression it can be concluded that the relationship between Islam and politics is both conceptually and politically very close. In Indonesia there are still three kinds of views regarding the relationship between Islam and politics. The three views are as follows: The first view says that Islam is different or has nothing to do with politics including the practical political movement. The most important Islamic figure who built this understanding and thought was Ali Abd. Raziq, and Thaha Husein. This can be illustrated in the following figure 1. 


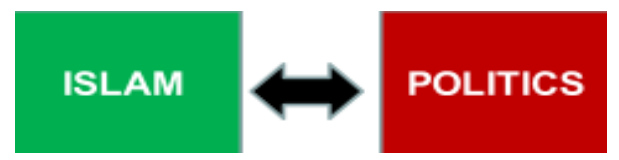

Figure1

The second view states that Islam is a view of life that is not merely related to vertical relations (hablum-minallah), rituals "mahdhah" human relations with God, but Islam also regulates horizontal relations (hablum-min-annas), between humans and humans, the ritual "ghairu mahdhah". In this kind of understanding it does not distinguish between Islamic affairs and political affairs. Islam teaches the politics of "siasah syariyyah", politics (a strategy based on Islamic principles). Key figures in this understanding include Hasan al-Bana, Seyyed Qutb, Rasyid Rida and Al-Maududi. This can be illustrated in the following figure 2 .

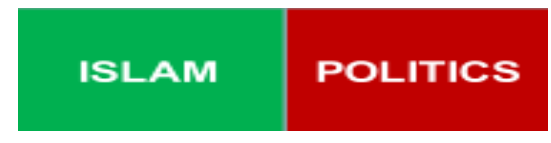

Figure2

The third view is rejecting the statement that Islam is not the same as politics (the first group) and also rejects the statement that Islam is identical with politics (the second group). This third group according to his understanding states that Islam contains in it regulates human life, ethical issues, value problems, leadership problems, and political life. In terms of politics, Islam does not directly deal with politics, but Islam provides general principles and foundations and rules related to human behavior in society and state. The basic values of Islam are used as guidelines and directors for everyone who pursues politics, especially practical politics. Important figures in this understanding include Muhammad Husain Haikal. This can be illustrated in the following figure 3.

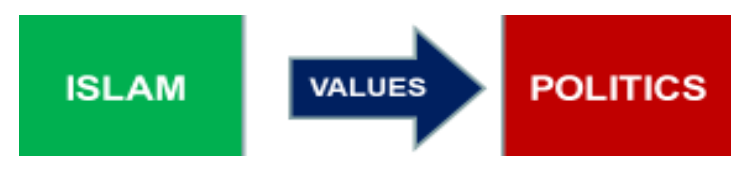

Figure3

\subsection{Difficult to Distinguish between Politics and Practical Politics}

Practical political or political problems among NU residents are indeed mostly unable to distinguish. Because politics is broadly meaningful. Whatever is done in the form of actions by people with certain goals both for themselves and for other groups can be called politics. In Arabic it is called "siasah" or "strategy" which has been adopted by Indonesian. While practical politics are often addressed to party politics, or movements that involve a lot of time to do certain goals. More concretely are political parties. Most Muslim community members already know the history and work of NU in the political world. This was obtained from lectures conducted by ulama or Kyai NU. Although the knowledge of practical politics and politics obtained by NU Muslim community members was given repeatedly, especially in the lead-up to the election or the president's choice, in general the NU Muslim community, knowledge about it, was not used as a main thing in NU Muslimat activities. For them it is more important to obey and tawaduk to the ulama or kyai. Ulama or kyai are all-everything in the NU tradition. Therefore what is said by clerics or clerics must be followed if they want to survive and enter heaven. So, understanding practical politics and politics is like what is understood by most Muslim citizens in general. Politics is a strategy in life. By scheming, we can survive the world and the hereafter. For example in the verse al-Qur'an it reads, meaning "guard yourself and your family from hellfire," this means that fortifying yourself and your family is very important. How to fortify it is by scheming. If my understanding is drawn more generally, to save myself, my family, Muslim community members, a place of struggle is needed, that is political parties. Political parties are a necessity that must be owned by Muslim NU citizens. This is where PKB is very important tosave NU citizens and NU Muslimat in order to maintain the mission of Islam in this country by placing its representatives on the board at the central, provincial and regional levels.

\subsection{Practical Politics for Gaining Power}

Associated with practical political or political understanding. In the NU Muslimat community, administrators often provide insight or knowledge about political concepts. In a general sense, politics 
is a human strategy to face all threats both from within and from outside. Because of that politics is very much related to religion, because if the religion adhered to faces a threat from the outside, we must fortify ourselves. In the history of Islam the political nuances are very thick especially in the post-Khulafur Rosyidun period, in Muawiyah's time, Abbasyiyah, until now between Shia and Sunnis. Therefore politics is needed for Muslims to know the global developments in the condition of Muslims in Indonesia, or in the world. Meanwhile, if it is called practical politics, politics is intended to gain power. The ingredients are party. NU Muslimat considers that both political and political practice is needed in Muslim life but the movement of the ummah and muslimat is more respected. The position of NU Muslimat only as a supporter and motivator by giving their votes to candidates from NU or NU Muslimat insofar as that support received the blessing of the NU clerics or clerics. NU Muslimat will obey and follow all the orders and direction of the clerics and clerics whether it is related to community activities in general or those related to politics.

\subsection{Life is political}

With sufficient experience in the legislature and thanks to direct learning, one of the NU Muslimat administrators was able to distinguish between what is called practical politics and politics. Politics, according to him is all the effort made by everyone to obtain the convenience of life. In everyday life, we actually have played politics. Whatever we do in life to avoid all threats and challenges, it can be categorized as a political activity. Meanwhile, usually when we call practical politics, the understanding that emerges is party politics, calling the party. So there is indeed a difference between political and practical terms. The word "politics" has a broad meaning, while practical politics has a narrow meaning, which is related to party politics.

\subsection{Politics has a Broad Meaning While Practical Politics has a Narrow}

Next is about practical political and political understanding. In general the Muslim community of NU did not consider it important to understand practical political or political understanding. Politics is all efforts made by anyone to get a position or power. Power can be narrow or broad, depending on the goals to be achieved. Our lives are actually political. Without politics we cannot live until this moment. Usually the word politics is equated with tactics. Strategy also means strategy. So all the strategies that we do for this survival are politics. Meanwhile, if it is called practical politics, it will refer to party politics, or mass movements. So practical politics are pragmatic and narrow. In $52 \mathrm{NU}$ broke away from Masyumi and made NU as practical politics to get internal criticism and all NU exponents sought to restore NU to its original principle, namely as a socio-religious organization as the initial purpose of establishing this organization in 1926. But the event was also repeated in 1973 joined other Islamic organizations in charge of the United Development Party (PPP). It seems that NU did not give up on the previous bitter experiences. In 1998, after the reformation, NU approved the establishment of the National Awakening Party (PKB). This means that within NU's body, it is assumed that politics that do not have party parties are the same as they cannot play much role in this country. For this reason, they must fight for Islam through practical politics or party politics. On this basis, perhaps what prompted the establishment of PKB as a forum for the aspirations of the NU and NU Muslimat to express their political choices.

Politics has a broad meaning while practical politics has a narrow meaning, namely politics which prioritizes pragmatic interests. If NU already has a container in the form of a PKB party, the NU Muslim community must support and vote for the party or elect a council that has the same base, namely from NU or NU Muslim. As a board of NU, although he not a member of the council or a candidate for the council, he obliged to encourage and even force the Muslim community to support his joint candidates because if he is elected or so he will help the NU Muslim struggle in activities carried out to realize activities programs has been proclaimed by Muslimat. So it is mutually beneficial. On the organization's side, they will get funds to launch the activities, while the candidates will get support from NU Muslimat. That was the political meaning understood by NU Muslimat officials. If other people who are not from the NU Muslim organization who become the council, it is difficult to get something to support Muslimat activities.

\subsection{Politics Adheres to Islam}

$\mathrm{NU}$ is not only a group that moves on political interests, but NU and its exponents, including NU Muslimat, are important wings to bring and realize the Islamic mission in the form of fostering and 
fortifying Muslims in order to implement Islam in accordance with the madzab which is followed on the Ahlus Sunnah wal jamaah. So, knowledge about politics and practical politics for Muslim citizens was directly obtained for their involvement in practical politics in supporting support since PKB became NU's official party. Knowledge of "politics" is understood as the concept of "siasah" in fiqh lessons, namely all efforts and efforts made by everyone in order to defend themselves, their families, Islam, and the ummah, that is siasah or politics in Indonesian. Therefore, Islam may do politics because politics is a concept inherent in Islam itself. The term musyawarah (democracy), al-adalah (justice), morality (moral), ulama and so on are concepts that have been contained and discussed in Islamic teachings. It is just that NU Muslimat members who do not have a broad base of Islamic education sometimes find it difficult to distinguish between politics and political parties. The graduates of Islamic boarding schools certainly get the lessons of jurisprudence which among them discuss about, the character of leadership, justice, culture, morals and so on, including also "siasah syar'iyyah" Islamic politics, then, they have understood the difference between politics in research that is very general with politics in a narrow sense. All actions taken to preserve and maintain goodness for oneself, family, and Islam, and the ummah of Islam, are manifestations of politics in a broader sense. Meanwhile, if we think or do activities in a party container it is politics in a narrow sense.

\section{CONCLUSION}

From the aforementioned expressions, it can be concluded that the understanding of politicsis generally the same although some are different because the stock of knowledge is different. In general, citizens have a different understanding of politics and political practice. Politics in general terms is a strategy or "strategy" in Indonesian. Every human being in life and organization in maintaining its continuity is doing politics. In other words, we cannot live without politics. Because of that politics is involving thinking and understanding of the context of life. Meanwhile, people's understanding of practical politics is interpreted as an effort to achieve certain goals using the means of political parties.

\section{REFERENCES}

[1] Aboebakar. Sedjarah Hidup KH A. Wahid Hasyim. Djakarta, Panitia Buku Peringatan Alm. KH.A.Wahid Hasyim, 1957.

[2] Almond, Grabiel A. dan Sidney Verba. 1990. Budaya Politik, Tingkah Laku Politik danDemokrasi di Lima Negara (terj. Sahat Simamora), (Bumi Aksara, 1990), 13.

[3] Babbie, Earl. The Basics of Social Research (6th ed.). Belmont, California : Wadsworth Cengage, 2014. pp. 303-04.

[4] Budiardjo, Miriam. Dasar-Dasar Ilmu Politik, Cetakan :Edisi revisi: Cetakan kelima, 2012

[5] Creswell, J. W. Research Design : Qualitatave, Quantitative and Mixed Methods Approaches, 2009.

[6] Denzin, Norman K. \& Lincoln, Yvonna S. Handbook of Qualitative Research. Thousand Oaks London : Sage Publications, 1994.

[7] Fadeli, Soelaiman dan Mohammad Subhan. Antologi NU: sejarah, istilah, amaliah uswah. Surabaya: Khalista bekerjasama dengan Ta'lif Wan Nasyr (LTN NU) Jawa Timur. 2007.

[8] Haris, Munawir. 2015."Partisipasi Politik NU dan Kader Muslimat Dalam Lintas Sejarah", Al-Tahrir, vol. 15, No. 2 November $2015: 283-308$.

[9] Ishomuddin. Agama dan Budaya: Membaca Perspektif dalam Keberagamaan, UMMPress, 2006

[10] Kantaprawira, Rusadi. Sistem PolitikIndonesia; Suatu Model Pengantar. Sinar Baru. Jakarta, 1988.

[11] Linconln, Yvonna \& Guba, Egon G. Naturalistic Inquiry, Beverly Hill, Sage Publication, 1985.

[12] Miles, Matthew B. \& Huberman A.M., Johnny Saldana. Qualitative Data Analysis: An Expanded Sourcebook (edition 3), Thousand Oaks, CA: SAGE. 2014.

[13] Muktamar NU XIX, 28 Mei 1952 di Palembang, NOM menjadi badan otonom dari NU dengan nama baru Muslimat NU.

[14] Patton, Michael Quinn. Qualitative Evaluation Method. Beverly Hills: Printing, Sage, Publishing, Inc.

[15] Ridwan, Nur Kholik. NU dan Neoliberalisme : tantangan dan harapan menjelang satu abad. Yogyakarta, Lkis, 2008.

[16] Ritzer, George. Sosiologi Ilmu Pengetahuan Berparadigma Ganda, Penyadur, Alimandan, Jakarta, Rajawali Press, 1992.

[17] Ritzer, G. Sociological Theory, Second Edition, New York, Knopf, 1988. 
[18] Ritzer, G. dan Douglas J. Goodman. Teori Sosiologi Modern (edisi revisi). Yogyakarta, Kreasi Wacana, 2012.

[19] Ritzer, G. Sosiologi Ilmu Pengetahuan Berparadigma Ganda. Terjemahan Alimandan. Jakarta: Rajawali, 1992.

[20] Ritzer, G. Teori Sosiologi Modern, Terjemahan Tri Wibowo, Jakarta, Kencana, 2014.

[21] Ritzer, G., dan Goodman Douglas J.Teori Sosiologi Modern. Terjemahan Alimandan. Jakarta: Prenada Media, 2005

[22] Sjadzali, Munawir.Islam dan Tata Negara: Ajaran, Sejarah dan Pemikiran, Jakarta, UI Press, 1990.

[23] Soeprapto, H.R. Riyadi.Interaksionisme Simbolik; Perspektif Sosiologi Modern, Pustaka Pelajar, Yogyakarta, 2001.

[24] Zaenuri, Ahmad."Peran Nahdlatul Ulama sebagai Partai Politik Tahun 1952-1973 di Pasuruan"dalam buku Mengawal Peradaban Sebuah Pemikiran Seputar Pluralisme, Pendidikan, Sosial dan Budaya, Yogyakarta: Trussmedia Grafika, 2015.

[25] Wijaya, Albert. BudayaPolitik dan Pembangunan Ekonomi, Jakarta: LP3ES. 1982.

[26] Zuhri, Hj. Saifuddin (dkk).Sejarah Muslimat NahdlatulUlama. PP. Muslimat NU Jakarta, 1979.

\section{AUTHOR's BIOGRAPHY}

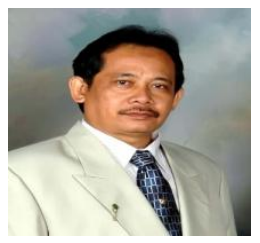

Professor Dr. Ishomuddin, M.Sc. Faculty of Islamic Education, University of Muhammadiyah Malang, Indonesia. "I feel proud that my article is published in this journal, so through this journal my article will be readable by many people".

Citation: Ishomuddin, et.al. "Culture and Political Understanding on Muslimat Nahdlatul Ulama (NU) in East Java". International Journal of Humanities Social Sciences and Education (IJHSSE), vol. 6, no.8, 2019, pp. 51-62. doi: http://dx.doi.org/10.20431/2349-0381.0608006.

Copyright: (c) 2019 Authors. This is an open-access article distributed under the terms of the Creative Commons Attribution License, which permits unrestricted use, distribution, and reproduction in any medium, provided the original author and source are credited. 